一つ，計三つのチューナを搭載している．当たり前だが, チューナは, すべて物理的なハードウェアであり, STBな どの機器のコストに上乗せされる.これが, IPTVサービ スであれば, ネットワークの帯域, STBの処理能力次第で, いくつものチャネルを扱うことができる.

もっとも，こういったデメリットは，新たな技術の開発 によって，おおむね解消されている. 言い換えると, ここ で挙げた四つが, ケーブル事業者にとってのIPTV化のメ リットであったわけだが, 現時点では, それらが概ね解消 されているというのが私の見解である.

\section{3. チャネルボンディングによる広帯域化}

ケーブル事業者が使用する変調方式である Q A M (Quadrature Amplitude Modulation)では，技術的には 1024QAMなども存在するが，扱いがシビアであり，フィ ールドで実際に使用している事業者はいない。 そこで登場 したのがチャネルボンディングと呼ばれる技術である.

これは, 複数のスロット (チャネル)を仮想的に組合せて 1本のネットワークのように見せる技術である. 例えば， 1 スロットあたり40Mbps程度の256QAMを，4スロット組合 せることで $160 \mathrm{Mbps}$ 実現する。無線LANの規格である

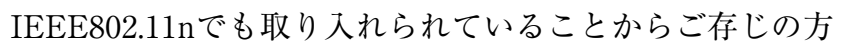
も多いと思うが，ケーブル事業者向けにもDOCSIS 3.0とい う名称で規格化がなされており, 国内でも，2007年より商 用サービスが始まっている。もっとも，2007年当時は DOCSIS3.0規格が最終FIXしておらず，その前段階である Pre-DOCSIS 3.0でのスタートであった.

技術的には32チャネルをボンディングすることで $1 \mathrm{Gbps}$ 以上を実現するという試みも行われており，実際に必要か どうかは別として, アクセススピードの広帯域化という意 味で, ケーブル事業者の自由度は高い. もっとも, 周波数 は有限であり，特定のサービスに多くのスロットを固定的 に割当てることは, ビジネスの採算上は問題が生じやすい. そこで, 並行して検討されてきたのがUniversal Edge QAMとERM (Edge Resource Manager)である.

従来は，スロットにサービスを割当てる際に使用する装 置が, サービスごとに異なっていた. その後, ケーブル事 業者がVODサービスを実現するために, Edge QAMと呼 ばれる装置が開発された。これは，特定のスロットに QAM変調で映像を流し込むためのもので，わかりやすく 書けば，IPネットワークの入力データを，64QAMに変換 する役割を持つ.この装置を汎用化することで, 異なるサ ービスでも同一のEdge QAMを使用できるようにする。こ れがUniversal Edge QAMという考え方である.さらに， それらを管理するためにERMを配置する。このERMは， サービスポリシーや実際の利用状況に応じて, 動的にサー ビスとEdge QAMのマッピングを行う。例えば，ERMの 管理下に12のスロットと, 二つのサービス, VODとDOCSIS 3.0を割当てたとする.この12のスロットをサービスポ
リシーや実際の利用状況に応じて，昼は四つをVOD，8つ をDOCSIS 3.0, 夜は8つをVOD，四つをDOCSIS 3.0という 具合に切替えていく.

後述するが，ケーブル事業者では，映像チャネルの割当 ても動的に行う試みが進んでおり，この場合にも Edge QAMを使用する。つまり，最終的には，すべてのスロッ トにEdge QAMを割当て, ERMにより動的に管理すると いった形態も考えられる.

実際には，スロット内での帯域管理も必要である。例え ば, J:COMの場合, VODサービスではSD (Standard Definition) 映像は3.6Mbps, HD (High Definition) 映像は $14.5 \mathrm{Mbps}$ で配信している。これをノードごとに概ね4スロ ットを割当てている. 各スロットでは64QAM変調を使用 しているため，実効帯域は約30Mbps.つまり，SDであれ ば8ストリーム，HDは2ストリームを配信できる。

現在のVODシステムは, 内部にEdge QAMの管理機能 を保有しており, それが, ユーザ (STB) からのリクエスト に応じて, 割当てられているスロットの中から空いている ものを探し，そこにストリームを送出している. STB側か ら見れば, VODシステムに映像の送出リクエストを送ると, スロット (周波数) とストリームIDが割当てられる。この スロットにテレビチューナを合わせ，ストリームを取得・ 表示するといメカニズムである.

これがERMが導入された場合, VODシステムは自ら Edge QAMを管理するのではなく，ERMに対してリソー スの割当て要求を出す。 ERMは, 自らの管理下にあるスロ ット全体から空いている帯域を探し, それを割当てる。こ れはスロットごとにサービスを割当ててもいいし, 例えば, VODと映像チャネルだけは同一スロットに割当てるといっ たことも可能である. VODや映像チャネルは, 使用する帯 域のバリエーションが少なく，またセッションが，ネット 系のサービスと比較すると圧倒的に長時間となるため, 帯 域の管理がしやすい。こういったサービスは，同一スロッ 卜内での混在も許可し，より効率的な配信を実現する。逆 に，トラフィックの摇れが大きく予想がしにくいインター ネットアクセス系のサービスでは, 割当てスロットをほか のサービスと混在することなく独立して割当てる.

このようにポリシーの異なるサービスを，スロット単位 で扱えるのがERMの特徴である.

\section{IPを使わないマルチキャスト配信}

映像チャネルのスロットへの動的な割当てに入る前に, J:COMが導入しているVODシステムについて説明する.こ れは, 将来の視聴形態により, そもそもマルチキャスト配 信にメリットがあるのかどうかが変わってくるためである.

J:COMのVODサービスでは, 映像の送出には64QAM, メニューや双方向信号のやりとりにはIPネットワークを使 用している. 映像の送出にIPネットワーク (技術)を使用し ていないのは, IPパケット化によりオーバヘッドが生じる 
にも関わらず，メリットがないからである．前述のとおり， VODの映像ストリームにはSDの3.6MbpsとHDの14.5Mbps の2通りしかなく，また送出サーバによってトラフィック が管理されているため, IP化の必要がない.

これに対してメニューや双方向信号のやりとりでIP技術 を使用しているのは，メニュー表現にWeb系の技術を使っ ているためである。 J:COMが映像サービスに使用している すべてのSTBには，共通仕様のWebブラウザが搭載されて いる.このWebブラウザには, 独自のVOD拡張を施して おり，HTMLとJavaScriptにより，VODのすべての機能が 制御可能である. 記述が容易なWeb系の技術を使うことで, メニューの改修を容易にするとともに, A j a x (Asynchromous Java Script+XML) の利用による表示の高 速化, SaaS (Software as a Service) によるレコメンドサー ビスの導入なども行っている，つまり，映像のような大容 量のデータを単純に配信する部分ではIP化によるオーバへ ッドを避け，メニューのように記述性が重要になる部分， および，インターネット上のさまざまなサーバと連携した 高度なサービスを実現するために，IP技術を取り入れてい る.IPTVサービスの定義では，よく「映像をIPパケットで 伝送する」ことが重要視されるが，IP化によるメリットを 追求した場合，上述のような形態が望ましいのではないか. 参考までに，VODシステムのバックエンド，およびバッ クボーン部分は，すでに大半がIP化されている，J:COMの 場合，VODサービスを提供するために3階層のネットワー クを使用している。もっとも上位に位置するのが，コンテ ンツを全国に配信するための1次ネットワークであり，こ こから全国3カ所のマスタヘッドエンドにコンテンッが伝 送される。マスタヘッドエンドには，ビデオポンプやスト レージ，バックエンドの管理システムといったVODシステ ム群が設置されており，原則，マスタヘッドエンド単位で 機能している.さらに，その下には50力所程度のローカル ヘッドエンドが配置される.

マスタヘッドエンドとローカルヘッドエンドは，エリア によって異なるが，10Gbpsから80Gbps程度のファイバに よるリング状のネットワークが複数設置されている. いず れかのリングにローカルヘッドエンドがつながるわけであ る。ここまでは，すべてIPネットワークを使用している。 そして，もっともアクセスネットワークに近いローカルヘ ッドエンドで，前述のEdge QAMを使用して，64QAMへ の変換を行い, STBに映像を送出している，つまり，IP技 術を使っていないのは，ローカルヘッドエンドからSTBへの 映像配信を行う部分のみであり，それ以外のすべてはIP技術 によって構築されたVODシステムである.

\subsection{SDVサービスによるチャネルの動的割当て}

CATVサービスでは, 地上デジタル放送やBSデジタル放 送に加えて，自主のデジタル放送を配信している．J:COM では，これをケーブルデジタル放送と呼び，エリアによっ て若干異なるが50チャネル程度を扱っている.
配信においては，地上波やBSなどの衛星放送と異なり， ケーブルを使用する．このケーブルを使った配信の最小単 位をノードと呼ぶ. J:COMの場合で言えば，ノードがカバ ーするエリアのホームパス (配信可能世帯) は概ね2,000世 帯程度，その中で実際に有料の契約をしている世帯は500 程度である。つまり，ノード単位で考えると，500世帯程 度を最小単位として, 地上デジタル放送, BSデジタル放送, それにディジタルケーブルテレビを合わせて70〜80チャネ ル程度を配信していることとなる，実際には，全世帯が常 にテレビを視聴していることはなく，また，チャネルごと に視聴率 (視聴数) に大きなばらつきが生じるため，結果と して，ノード単位で考えると，誰も見ていないチャネルが 存在することとなる.

この無駄を解消し，より多くの映像チャネルを配信可能 とするために考え出されたのが, SDV (Switched Digital Video）である。内容は，IPTVにおけるマルチキャスト配 信と似ている．SDVに対してスロットを割当て，各スロッ トからはEdge QAMを通じて映像チャネルを配信（放送） する.すべてのスロットにEdge QAMを割当てるため，複 数のノードをまとめたサービスグループという考え方を導 入することで, 必要なEdge QAMの数を減らしている. ード単位の配信にすると，ノード数×対象スロット数分の Edge QAMが必要となるためである.

SDVで配信される映像チャネルは，サービスグループ内 で，最低1台以上のSTBから視聴リクエストがなければ配 信されない，実際の仕組みは，日本ではデー夕放送の配信 に使われているカルーセル伝送を使う。現在，サービスグ ループ内で配信されているチャネルIDとスロット(周波数)， それに配信IDが記述されたテーブルを，短い周期でカルー セル伝送することで，STBは，チャネルが配信されている かどうか，配信されている場合は，どのスロットにあるか を把握する，もし，配信されていない場合は，SDVサーバ に対し配信リクエストを送ると，空きスロットが割当てら れ配信が始まる仕組みである。

日本で，このSDVを導入しているケーブル事業者は2009 年3月時点ではいないが，北米では，すでに商用ベースで 利用している事業者がいる．北米では，チャネル数が 200 〜300と日本と比べて数が多い上に，チャネルラインナッ プにはスペイン語やフランス語の放送など，エリアの住民 構成によって視聴数が大きく異なる傾向にあることも要因 で, SDVの効果が得やすいからである.

北米で実際に導入されているSDVシステムでは, サービ スグループ内で映像チャネルが配信されていなかった場合 でも，100〜200ms程度で映像を立ち上げている．つまり， 視聴者から見れば，SDVを導入してもレスポンスにほとん ど影響は出ていない，また，STBの場合，電源を入れっぱ なしにしている視聴者も多い. マイナーなチャネルを選局 した状態で放置されるとSDVの効果を損なうため，一定時 間以上, STBの操作がないと，画面上の視聴確認のダイア 
ログを表示し，それでも操作がない場合は，特定チャネル に切替えるといった制御も行われている。これらにより， SDVを導入することで，130～200\%程度の効率化が実現で きている，つまり，例えばSDVを導入しない状態では10チ ヤネルしか配信できなかった周波数帯で, SDVを導入する と13〜20チャネルが配信できているという.

SDVシステムは, センター設備で見ると, VODシステム と大半を共有できる. むしろ, サービスグループ内で複数 のSTBからリクエストがあった場合でも，1本のストリー ムしか配信する必要がないことから, 簡易型のVODシステ ムとして位置づける場合もある.

さらに逆の発想として, 既存のVODシステムに, ほとん ど手を加えずに，簡易型SDVを実現する取組みもある．前 述のとおり, SDVの導入効果が130〜 200\%程度が見込める ことを前提とすると, 最大で半数程度は視聴者数がゼロと いうことになる，この場合，配信されているチャネルであ っても, 視聴者数は 1 前後であるものが多く存在すること になる，ならば，対象チャネルを事前に絞り込めば，わざ わざマルチキャストで配信するのではなく, ユニキャスト, つまり既存のVODシステムを使って配信しても, さほどオ ーバヘッドは生じないという考え方である。これを簡易型 のSDVと呼ぶ. 簡易型SDVのメリットは, VODシステム の改修インパクトが極めて小さい点である．ただ，これを 商用サービスに適用している事業者はまだ存在しない。

\section{2 放送のユニキャスト化}

SDVにより, マイナーなチャネルの動的な割当てが進む のと並行して, メジャーなチャネルのユニキャスト化も進 んでいる. DVRの普及により, タイムシフト視聴に慣れた 視聴者が，自由な視聴形態を望むからである.

これに応えるために，ケーブル事業者は「Time Shift」, $\lceil$ Catch Up」と呼ぶ二つの視聴形態を用意している. Time Shiftは, 現在, 放送されている番組でトリックプレイを可 能とする形態である．視聴者が放送を見ている最中に，リ モコン操作などで映像を一時停止したり, 番組の先頭に戻 したりできる，実際には，リモコン操作がされた段階で, 放送 (ブロードキャスト) からVOD (ユニキャスト)に切替 わる. 北米ではTimeWarner CableがStart Overというサ ービス名称で実現している. Start Overの場合は, コンテ ンツの権利者との調整で早送りを禁止するとともに, 利用 できる期間を該当番組が放送されている時間帯に限ってい る.つまり 2 時から 2 時54分まで番組が放送されている場合, その時間内であれば自由に一時停止や巻き戻しが可能であ り，一度，Start Overモード (VOD)に移行してしまえば, 2時54分を過ぎても自由に視聴できる。ただし，このStart Overモードに移行できるのは，2時から2時54分までという 制限を付けている. これにより, 番組の時間軸による編成 というポリシーを変えず，またCMスキップなどを抑制し つつ, ユーザの利便性向上を実現した。このサービスは普 及が加速しており, Time Warner Cableの場合, エリアに
よっても異なるが，対象チャネルは70〜100程度，同時視 聴数も15〜20\%程度になっているという.

もう一つのCatch Upサービスは，ケーブル事業者によっ て厳密な定義は異なるが, 概ね, 番組放送後に, 放送され た番組コンテンツ，もしくは関連するコンテンツをVODで サービスするものである. 北米ではComcastなどが，チャ ネルに関連したコンテンツを多数, VODで無料提供してお り，大きな人気を集めている，つまり，SDVやTime Shift, Catch Upにより, 従来はスロットを固定的に割当てて放送 していた映像チャネルが，動的にスロットを割当てて，か つユニキャストで配信する方向へ，急激にシフトしている のが現状である.

\section{5.むす び}

冒頭で書いたスロット単位でチューナが必要である点 に, 現時点では抜本的な解決策はない。複数の映像チャネ ルを一括して表示する場合に, STB側で受信・合成するの ではなく，センター側であらかじめ合成したものを配信す るソリューション (一部, 事業者ではMosaicサービスと呼 ばれている) がある程度である.

それ以外の項目については，すでに技術が開発され，多 くは商用サービスで使用されている，つまり，IPTVサー ビスでのみ提供可能で, ケーブル事業者で技術的に提供で きないものはないという認識である.

それでは，もし将来，ケーブル事業者がIPTV化してい く必要が生じるとしたら, それはどういう未来なのかを最 後にまとめておきたい.

まずは，アクセスネットワークが，今以上に高速化した 場合である．FTTHサービスでは100Mbpsから1Gbps程度 のサービスが存在するが，ケーブル事業者のHFCネットワ ークでも，すべてのスロットを使えば3 Gbps程度を発揮す ることができ，このレベルではIP化する必要がない。これ が10Gbps以上になれば, 多様なサービスを物理的な1本の ケーブルで配信する場合には，明確な意味を持つであろう。

そして，もう一つは映像サービス・双方向サービスの多様 化である. 現在のように, SDとHDの2種類をシンプルに送 り, 双方向といっても, 簡単な制御信号のやりとりをする だけではIP化の意味はない.ここにUGC (User Generated Contents) などが加わり, さまざまな帯域が使われたり, 複 数のセンター・サーバや, 場合によってはユーザ宅の機器 が複雑に連携した双方向サービスが実現された場合, 初め て意味を持つのではないか.

(2009年3月30日受付)

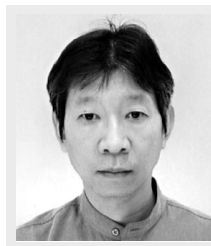

㕸笠茾康伸 (株) ジュピターテレコム商品戦略本 部所属. 主に, 双方向ディジタルテレビサービスの商 品企画, および, システム開発に従事.

(49) 621 